\title{
Effect of Some Slimming Drugs on Some Biochemical and Physiological Parameters of Albino Rats
}

\author{
Eman G.E. Helal *, Ali A. Shati** and Fahmy G. Elsaid***\# \\ *Zoology dep., Faculty of Science, Al-Azhar University, Egypt. \\ **Life Science Dep., Faculty of Science, King Khalid University, KSA. \\ \#Zoology Dep., Faculty of Science, Mansoura University, Egypt.
}

\begin{abstract}
:
Background: The slimming drugs differ in their nature, where apple-lite is a fully natural substance, mirapro- $\mathrm{N}$ is a chemical substance and tenuate is a synthetic foamy filler substance. The study aimed to search the physiological and biochemical changes accompanied with these drugs on rats.

Methods: Forty adult male albino rats $(130 \pm 20 \mathrm{~g})$ were divided into four groups, ten on each treated group and ten for the control one. The apple-lite group treated with $3.5 \mathrm{mg} / 100 \mathrm{~g}$ body weight, the mirapro- $\mathrm{N}$ group treated with $0.14 \mathrm{mg} / 100 \mathrm{~g}$ body weight and the tenuate group treated with 0.1 $\mathrm{mg} / 100 \mathrm{~g}$ body weight.

Results: The treated groups showed a significant changes in the lipid and protein profiles, enzymatic activities, in the skin folds and the percentage of body weight compared to the control group.

In conclusion, the slimming drugs showed a change in skin folds thickness and in percentage of organ's weight to body weight and also showed a deflection in the investigated biochemical parameters.

Key words: slimming drugs, tenuate, apple-lite, mirapro-N, lipid profile, liver function, skin folds.
\end{abstract}

\section{Introduction:}

Obesity frequently increased at the last decade. It possesses a serious health hazard and its treatment is often disappointing. Aronne (1998) showed that since the withdrawal of the anorectic agents, phentermine and fenfluramine from the worldwide market, orlistat is at this time the only drug approved by the European community for treatment of obesity. Anorexic drugs differ according to the mode of action. Many authors study the safety, evaluation and efficacy of ant obesity drugs of different mode of action (Aronne 1998; Hvizdos and Markham ; Scheen et al., 1999; Marks 2001). Accordingly to Alemany et al., (2003) there are three major classes of drugs for the treatment of obesity: (i) inhibitors of food intake, which reduce hunger perception and, consequently food intake, the most representative are centrally acting neurotransmitters and intestinal or neural satiety peptides; (ii) inhibitors of nutrient absorption, which reduce energy disposal through a peripheral gastro-intestinal mechanism and (iii) thermogenic drugs, which increase energy expenditure. However, the two long term use drugs aresibu-tramine, an inhibitor of both serotonin and norepinephrine reuptake and orlistat, a lipase inhibitor that targets pancreatic lipase and reduces absorption of fats. Orlistat is a novel non-systemic treatment for obesity; it inhibits lipases in the gastrointestinal tract, preventing the absorption of approximately 30\% of dietary fats (Hvizdos and Markham 1999). Dose of orlistat $(120 \mathrm{mg}, 3$ times daily with each main meal), is optimal. Gockcel et al., (2002) concluded that sibutramine, orlistat and metformine were all effective and safe medications that reduce cadiovascular risk of type-II diabetes mellitus in obese females. Overall, treatment with $10 \mathrm{mg}$ sibutramine is more effective than orlistat or metformine therapy in terms of weight reduction. Glazer (2001) stated that the weight loss attributable to obesity pharmacotherapy in trials lasting 36 to 52 weeks was $7.9 \mathrm{~kg}$ for those receiving sibutramine resin, $4.3 \mathrm{~kg}$ for those receiving sibutramine hydrochloride, $3.4 \mathrm{~kg}$ for those receiving orlistat and $1.5 \mathrm{~kg}$ for those receiving diethylpropion hydrochloride "tenuate". Physiological, pathological and epidemi-ological studies strongly support that anorexia induced valvulopathy is attributed to specific serotogenic properties of the fenfluramines. Orlistat (an oral 
intestinal lipase inhibitor and fat absorption blocker) is a pancreatic lipase inhibitor, which nonsystematically decreases gastrointestinal fat absorption without affecting psychotropic drug plasma levels (Hilger et al., 2002).

Conductier et al., (2005) revealed that3,4-methylene-N-methanep-hetamine or "ecstasy" is a psychoactive substance, first described as an appetite suppressant in humans inducing side effects and even death. The study was designed to investigate the effects of three different slimming drugs and their side effects. In the present study, slimming drugs of different sources, natural (apple-fibers and gel) as apple-lite, syntheticfoamy substance as tenuate and chemically as mirapro-N are used to evaluate their effects on physiological and biochemical parameters in experimental rats.

Material and Methods:

Forty mature males albino rats weighing about $130 \pm 20 \mathrm{~g}$ were used in this study. Animals were kept under good ventilation and received balanced diet and water ad libitum throughout the experiment. The animals were then divided into four groups; the first group was the control (10 rats) without treatment; the second, the third and the fourth groups (10/group) received apple-lite at dose of $3.5 \mathrm{mg} / 100 \mathrm{~g}$, mirapro- $\mathrm{N}$ at dose of 0.14 $\mathrm{mg} / 100 \mathrm{~g}$ and tenuate at dose $0.1 \mathrm{mg} / 100 \mathrm{~g}$ respectively. All doses were calculated according to Paget and Bernes (1973) and the drugs were given orally for 30 consecutive days. After 30 days of treatment, 5 animals of each group were decapitated, while the other 5 animals were kept for 15 days (recovery period) without any treatment. Blood samples were collected and homogenized and sera were collected and kept at $-4^{\circ} \mathrm{C}$ for later biochemical analysis. Also the tissue samples of brain, heart, liver, kidney, testis and spleen were weighed and homogenized and made $10 \%$ dilution with saline $0.9 \% \mathrm{NaCl}$ and kept at $-4^{\circ} \mathrm{C}$ for later biochemical analysis.

Skin-fold and body weight:

The body weight of each rat was recorded at the beginning of treatment period and at the end of recovery period for calculation of the body weight changes. Measuring of skin-fold thickness was done after shaving hair at tested sites using special micrometer according to the method of Franzini and Grimes (1976).

Biochemical changes:

Acid phosphatase and non-prostatic acid phosphatase were determined according to the method of Kind and King (1954). AST and ALT activeties were accomplished using the method of Reitman and Frankel (1975).

Lactic dehydrogenase (LDH) activity was determined according to Raabo (1963).

Albumin was evaluated according to the method of Webster (1977), while total proteins content were estimated using the Biuret method as described by Doumas (1975).

Total lipids were determined according to the method of Knight et al.(1972), while, triglycerides were determined by the method of Rojkin et al., (1974). Serum total cholesterol was determined as mentioned by Fossati and Medici (1987).

Serum glucose determination was based on the enzymatic method described by Siest and Schielf (1981).

Statistical analysis:

The data recorded were expressed as mean $\pm \mathrm{SD}$ and statistical and correlation analyses were undertaken using the One-way ANOVA followed by post-hoc LSD (Least Significant Difference) test. A P value $<0.05$ was accepted statistically significant. Statistical analysis was performed with Statistical Package for the Social Sciences for Windows (SPSS, version 10.0, USA). 


\section{Results:}

Table (1): Effect of anorexic drugs, apple-lite, mirapro- $\mathrm{N}$ and tenuate on skin-fold thickness of gluteal, back and bely regions after treatment and recovery periods:

\begin{tabular}{|c|c|c|c|c|c|c|c|c|c|c|}
\hline \multirow{2}{*}{\multicolumn{2}{|c|}{ Parameters }} & \multirow[t]{2}{*}{ Groups } & \multicolumn{4}{|c|}{ Treated period } & \multicolumn{4}{|c|}{ Recovery period } \\
\hline & & & Control & Apple-lite & Mirapro-N & Tenuate & Control & Apple-lite & Mirapro-N & Tenuate \\
\hline \multirow{3}{*}{$\frac{\bar{\theta}}{\frac{1}{\pi}}$} & $\begin{array}{l}\text { Gluteal } \\
(\mathbf{m m})\end{array}$ & $\begin{array}{l}m \pm \\
S D \\
P\end{array}$ & $\begin{array}{l}0.99 \pm \\
0.07\end{array}$ & $\begin{array}{l}0.85 \pm \\
0.05 \\
>0.001\end{array}$ & $\begin{array}{l}0.84 \pm \\
0.1 \\
>0.001\end{array}$ & $\begin{array}{l}0.81 \pm \\
.07 \\
>0.001\end{array}$ & $\begin{array}{l}1.07 \pm \\
0.1\end{array}$ & $\begin{array}{l}0.91 \pm \\
0.04 \\
>0.01\end{array}$ & $\begin{array}{l}0.89 \pm \\
0.74 \\
>0.01\end{array}$ & $\begin{array}{l}0.9 \pm \\
0.07 \\
>0.05\end{array}$ \\
\hline & $\begin{array}{l}\text { Back } \\
(\mathbf{m m})\end{array}$ & $\begin{array}{l}\mathrm{m} \pm \\
\mathrm{SD} \\
\mathrm{P}\end{array}$ & $\begin{array}{l}0.85 \pm \\
0.06\end{array}$ & $\begin{array}{l}0.73 \pm \\
0.06 \\
>0.01\end{array}$ & $\begin{array}{l}0.7 \pm \\
0.1 \\
>0.001\end{array}$ & $\begin{array}{l}0.76 \pm \\
0.1 \\
>0.05\end{array}$ & $\begin{array}{l}0.96 \pm \\
0.04\end{array}$ & $\begin{array}{l}0.84 \pm \\
0.06 \\
>0.01\end{array}$ & $\begin{array}{l}0.9 \pm \\
0.07 \\
\text { N.S. }\end{array}$ & $\begin{array}{l}0.9 \pm \\
0.03 \\
>0.05\end{array}$ \\
\hline & $\begin{array}{l}\text { Belly } \\
(\mathrm{mm})\end{array}$ & $\begin{array}{l}m \pm \\
S D \\
P\end{array}$ & $\begin{array}{l}0.6 \pm \\
0.05\end{array}$ & $\begin{array}{l}0.56 \pm \\
0.04 \\
\text { N.S. }\end{array}$ & $\begin{array}{l}0.5 \pm \\
0.04 \\
>0.01\end{array}$ & $\begin{array}{l}0.48 \pm \\
0.03 \\
>0.001\end{array}$ & $\begin{array}{l}0.6 \pm \\
0.1\end{array}$ & $\begin{array}{l}0.56 \pm \\
0.04 \\
\text { N.S. }\end{array}$ & $\begin{array}{l}0.5 \pm \\
0.04 \\
>0.01\end{array}$ & $\begin{array}{l}0.48 \pm \\
0.03 \\
>0.001\end{array}$ \\
\hline
\end{tabular}

$\mathrm{P}>0.05$ non-significant, $\mathrm{P}<0.05$ significant , $\mathrm{P} \leq 0.01$ highly significant , $\mathrm{P} \leq 0.001$ very highly significant

Table (2): Effect of anorexic drugs, apple-lite, mirapro- $\mathrm{N}$ and tenuate on the percentage of organ weight/body weight after treatment and recovery periods:

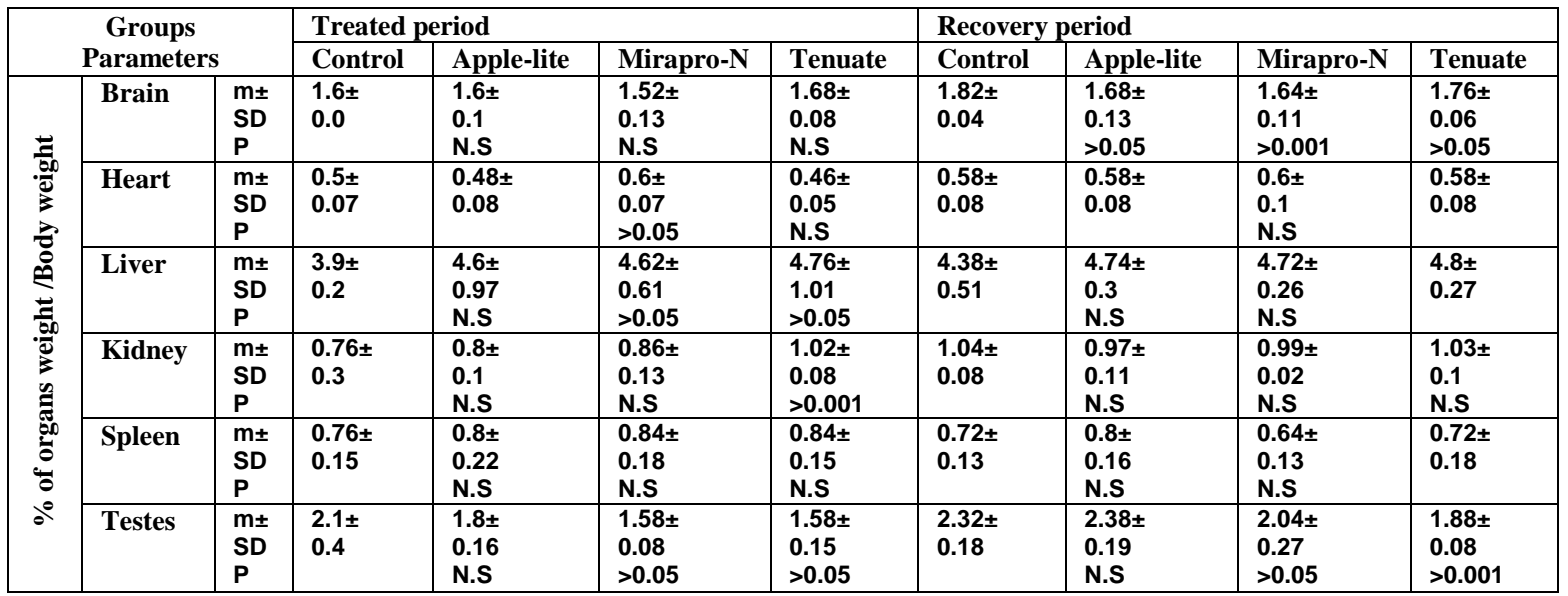

$\mathrm{P}>0.05$ non-significant, $\mathrm{P}<0.05$ significant, $\mathrm{P} \leq 0.01$ highly significant, $\mathrm{P} \leq 0.001$ very highly significant 
Table (3): Effect of anorexic drugs, apple-lite, mirapro-N and tenuate onprostatic and total acid phosphatase, AST, ALT and LDH activities and plasma proteins after treatment and recovery periods:

\begin{tabular}{|c|c|c|c|c|c|c|c|c|c|}
\hline \multirow{2}{*}{\multicolumn{2}{|c|}{$\begin{array}{ll}\text { Groups } & \text { Garameters }\end{array}$}} & \multicolumn{4}{|c|}{ Treated period } & \multicolumn{4}{|c|}{ Recovery period } \\
\hline & & Control & $\begin{array}{l}\text { Apple- } \\
\text { lite }\end{array}$ & Mirapro-N & Tenuate & Control & $\begin{array}{l}\text { Apple- } \\
\text { lite }\end{array}$ & Mirapro-N & Tenuate \\
\hline $\begin{array}{l}\text { Prostatic acid } \\
\text { phosphatase }\end{array}$ & $\begin{array}{l}\mathrm{m} \pm \\
\text { SD } \\
\mathrm{P}\end{array}$ & $\begin{array}{l}2.3 \pm \\
0.75\end{array}$ & $\begin{array}{l}2.5 \pm \\
0.11 \\
\text { N.S }\end{array}$ & $\begin{array}{l}2.8 \pm \\
0.15 \\
<0.05\end{array}$ & $\begin{array}{l}3.08 \pm \\
0.24 \\
\text { N.S }\end{array}$ & $\begin{array}{l}2.7 \pm \\
0.41\end{array}$ & $\begin{array}{l}2.1 \pm \\
0.13 \\
<0.01\end{array}$ & $\begin{array}{l}2.4 \pm \\
0.05 \\
\text { N.S }\end{array}$ & $\begin{array}{l}2.3 \pm \\
0.21 \\
\text { N.S }\end{array}$ \\
\hline $\begin{array}{l}\text { Total acid } \\
\text { phosphatase }\end{array}$ & $\begin{array}{l}\mathrm{m} \pm \\
\text { SD } \\
\mathrm{P}\end{array}$ & $\begin{array}{l}58 \pm \\
6\end{array}$ & $\begin{array}{l}60.6 \pm \\
3.8 \\
\text { N.S }\end{array}$ & $\begin{array}{l}61 \pm \\
3.7 \\
\text { N.S }\end{array}$ & $\begin{array}{l}67.8 \pm \\
4.9 \\
<0.001\end{array}$ & $\begin{array}{l}61.4 \pm \\
6.1\end{array}$ & $\begin{array}{l}61 \pm \\
2.2 \\
\text { N.S }\end{array}$ & $\begin{array}{l}55.8 \pm \\
4.3 \\
<0.05\end{array}$ & $\begin{array}{l}62.2 \pm \\
2.3 \\
\text { N.S }\end{array}$ \\
\hline Serum AST & $\begin{array}{l}\mathrm{m} \pm \\
\mathrm{SD} \\
\mathrm{P}\end{array}$ & $\begin{array}{l}44.4 \pm \\
1.8\end{array}$ & $\begin{array}{l}49 \pm \\
4.4 \\
\text { N.S }\end{array}$ & $\begin{array}{l}53.6 \pm \\
7.7 \\
\text { N.S }\end{array}$ & $\begin{array}{l}60.4 \pm \\
9.2 \\
<0.01\end{array}$ & $\begin{array}{l}36.2 \pm \\
18\end{array}$ & $\begin{array}{l}42.6 \pm \\
2.5 \\
\text { N.S }\end{array}$ & $\begin{array}{l}33.8 \pm \\
16.8 \\
\text { N.S }\end{array}$ & $\begin{array}{l}45.4 \pm \\
3.5 \\
\text { N.S }\end{array}$ \\
\hline Serum ALT & $\begin{array}{l}\mathrm{m} \pm \\
\text { SD } \\
\mathrm{P}\end{array}$ & $\begin{array}{l}40.2 \pm \\
1.1\end{array}$ & $\begin{array}{l}43.2 \pm \\
1.6 \\
\text { N.S }\end{array}$ & $\begin{array}{l}45.4 \pm \\
1.8 \\
\text { N.S }\end{array}$ & $\begin{array}{l}39.6 \pm \\
19.6 \\
\text { N.S }\end{array}$ & $\begin{array}{l}36.6 \pm \\
4.2\end{array}$ & $\begin{array}{l}40 \pm \\
1.2 \\
\text { N.S }\end{array}$ & $\begin{array}{l}30.6 \pm \\
1.3 \\
\text { N.S }\end{array}$ & $\begin{array}{l}34.6 \pm \\
3.5 \\
\text { N.S }\end{array}$ \\
\hline Serum LDH & $\begin{array}{l}\mathrm{m} \pm \\
\mathrm{SD} \\
\mathrm{P}\end{array}$ & $\begin{array}{l}117 \pm \\
5.9\end{array}$ & $\begin{array}{l}125.6 \pm \\
3.7 \\
<0.05\end{array}$ & $\begin{array}{l}131 \pm \\
7.1 \\
<0.001\end{array}$ & $\begin{array}{l}154 \pm \\
11.4 \\
<0.01\end{array}$ & $\begin{array}{l}105 \pm \\
5.1\end{array}$ & $\begin{array}{l}128 \pm \\
7.6 \\
<0.001\end{array}$ & $\begin{array}{l}139.2 \pm \\
4.3 \\
<0.001\end{array}$ & $\begin{array}{l}161.2 \pm \\
11.3 \\
<0.001\end{array}$ \\
\hline Serum albumin & $\begin{array}{l}\mathrm{m} \pm \\
\text { SD } \\
\mathrm{P}\end{array}$ & $\begin{array}{l}4.8 \pm \\
0.38\end{array}$ & $\begin{array}{l}4.5 \pm \\
0.48 \\
\text { N.S }\end{array}$ & $\begin{array}{l}3.8 \pm \\
0.59 \\
<0.001\end{array}$ & $\begin{array}{l}3.4 \pm \\
0.29 \\
<0.001\end{array}$ & $\begin{array}{l}3.9 \pm \\
0.54\end{array}$ & $\begin{array}{l}3.7 \pm \\
0.27 \\
\text { N.S }\end{array}$ & $\begin{array}{l}3.5 \pm \\
0.35 \\
\text { N.S }\end{array}$ & $\begin{array}{l}3.4 \pm \\
0.41 \\
\text { N.S }\end{array}$ \\
\hline Serum globulin & $\begin{array}{l}\mathrm{m} \pm \\
\text { SD } \\
P\end{array}$ & $\begin{array}{l}2.6 \pm \\
0.49\end{array}$ & $\begin{array}{l}2.9 \pm \\
0.22 \\
\text { N.S }\end{array}$ & $\begin{array}{l}2.4 \pm \\
0.47 \\
\text { N.S }\end{array}$ & $\begin{array}{l}2.3 \pm \\
0.22 \\
\text { N.S }\end{array}$ & $\begin{array}{l}3.1 \pm \\
0.84\end{array}$ & $\begin{array}{l}2.3 \pm \\
0.68 \\
<0.05\end{array}$ & $\begin{array}{l}2.9 \pm \\
0.38 \\
\text { N.S }\end{array}$ & $\begin{array}{l}2.8 \pm \\
0.56 \\
\text { N.S }\end{array}$ \\
\hline A/G ratio & $\begin{array}{l}\mathrm{m} \pm \\
\text { SD } \\
P\end{array}$ & $\begin{array}{l}1.8 \pm \\
0.3\end{array}$ & $\begin{array}{l}1.7 \pm \\
0.12 \\
\text { N.S }\end{array}$ & $\begin{array}{l}1.6 \pm \\
0.61 \\
\text { N.S }\end{array}$ & $\begin{array}{l}1.5 \pm \\
0.23 \\
\text { N.S }\end{array}$ & $\begin{array}{l}1.8 \pm \\
0.3\end{array}$ & $\begin{array}{l}1.7 \pm \\
0.12 \\
\text { N.S }\end{array}$ & $\begin{array}{l}1.6 \pm \\
0.61 \\
\text { N.S }\end{array}$ & $\begin{array}{l}1.5 \pm \\
0.24 \\
\text { N.S }\end{array}$ \\
\hline
\end{tabular}

$\mathrm{P}>0.05$ non-significant, $\mathrm{P}<0.05$ significant, $\mathrm{P} \leq 0.01$ highly significant, $\mathrm{P} \leq 0.001$ very highly significant

Table (4): Effect of anorexic drugs, apple-lite, mirapro-N and tenuate on sera total lipids, triglycerides, cholesterol and glucose levels after treatment and recovery periods:

\begin{tabular}{|c|c|c|c|c|c|c|c|c|c|}
\hline \multirow[b]{2}{*}{ Parameters } & \multirow[t]{2}{*}{ Groups } & \multicolumn{4}{|c|}{ Treated period } & \multicolumn{4}{|c|}{ Recovery period } \\
\hline & & Control & Apple-lite & Mirapro-N & Tenuate & Control & Apple-lite & Mirapro-N & Tenuate \\
\hline $\begin{array}{l}\text { Serum } \\
\text { total lipids }\end{array}$ & $\begin{array}{l}\mathrm{m} \pm \\
\mathrm{SD} \\
\mathrm{P}\end{array}$ & $\begin{array}{l}366 \pm \\
11.4\end{array}$ & $\begin{array}{l}348 \pm \\
8.3 \\
\text { N.S }\end{array}$ & $\begin{array}{l}346 \pm \\
11.4 \\
\text { N.S }\end{array}$ & $\begin{array}{l}334 \pm \\
11.4 \\
\text { N.S }\end{array}$ & $\begin{array}{l}366 \pm \\
11.4\end{array}$ & $\begin{array}{l}348 \pm \\
8.3 \\
\text { N.S }\end{array}$ & $\begin{array}{l}283 \pm \\
13.9 \\
<0.01\end{array}$ & $\begin{array}{l}334 \pm \\
11.4 \\
\text { N.S }\end{array}$ \\
\hline $\begin{array}{l}\text { Serum } \\
\text { triglycerides }\end{array}$ & $\begin{array}{l}\mathrm{m} \pm \\
\mathrm{SD} \\
\mathrm{P}\end{array}$ & $\begin{array}{l}94 \pm \\
11.4\end{array}$ & $\begin{array}{l}84 \pm \\
11.4 \\
\text { N.S }\end{array}$ & $\begin{array}{l}82 \pm \\
11.5 \\
\text { N.S }\end{array}$ & $\begin{array}{l}82 \pm \\
8.4 \\
\text { N.S }\end{array}$ & $\begin{array}{l}96 \pm \\
8.9\end{array}$ & $\begin{array}{l}112 \pm \\
7.5 \\
<0.01\end{array}$ & $\begin{array}{l}101 \pm \\
11.4 \\
\text { N.S }\end{array}$ & $\begin{array}{l}100 \pm \\
15.8 \\
\text { N.S }\end{array}$ \\
\hline $\begin{array}{l}\text { Serum } \\
\text { cholesterol }\end{array}$ & $\begin{array}{l}\mathrm{m} \pm \\
\mathrm{SD} \\
\mathrm{P}\end{array}$ & $\begin{array}{l}149 \pm \\
11.4\end{array}$ & $\begin{array}{l}135 \pm \\
14.1 \\
\text { N.S }\end{array}$ & $\begin{array}{l}144 \pm \\
11.4 \\
\text { N.S }\end{array}$ & $\begin{array}{l}137 \pm \\
8.4 \\
\text { N.S }\end{array}$ & $\begin{array}{l}127 \pm \\
6.7 \\
\text { N.S }\end{array}$ & $\begin{array}{l}86.4 \pm \\
6.7 \\
<0.05\end{array}$ & $\begin{array}{l}133 \pm \\
4.5 \\
\text { N.S }\end{array}$ & $\begin{array}{l}110.6 \pm \\
5.4 \\
\text { N.S }\end{array}$ \\
\hline $\begin{array}{l}\text { Serum } \\
\text { protein }\end{array}$ & $\begin{array}{l}\mathrm{m} \pm \\
\mathrm{SD} \\
\mathrm{P}\end{array}$ & & $\begin{array}{l}7.1 \pm \\
0.69 \\
<0.001\end{array}$ & $\begin{array}{l}5.9 \pm \\
0.45 \\
<0.001\end{array}$ & $\begin{array}{l}6 \pm \\
0.35 \\
<0.01\end{array}$ & $\begin{array}{l}6.9 \pm \\
0.86\end{array}$ & $\begin{array}{l}6.4 \pm \\
0.42 \\
\text { N.S }\end{array}$ & $\begin{array}{l}6.5 \pm \\
0.35 \\
\text { N.S }\end{array}$ & $\begin{array}{l}6.1 \pm \\
0.46 \\
<0.05\end{array}$ \\
\hline $\begin{array}{l}\text { Serum } \\
\text { glucose }\end{array}$ & $\begin{array}{l}\mathrm{m} \pm \\
\mathrm{SD} \\
\mathrm{P}\end{array}$ & $\begin{array}{l}86.8 \pm \\
14\end{array}$ & $\begin{array}{l}81.6 \pm \\
12.8 \\
\text { N.S }\end{array}$ & $\begin{array}{l}76 \pm \\
7.4 \\
\text { N.S }\end{array}$ & $\begin{array}{l}99 \pm \\
14.3 \\
\text { N.S }\end{array}$ & $\begin{array}{l}98 \pm \\
8.4\end{array}$ & $\begin{array}{l}98 \pm \\
8.3 \\
\text { N.S }\end{array}$ & $\begin{array}{l}86 \pm \\
5.5 \\
\text { N.S }\end{array}$ & $\begin{array}{l}85 \pm \\
8.6 \\
<0.05\end{array}$ \\
\hline
\end{tabular}

$\mathrm{P}>0.05$ non-significant, $\mathrm{P}<0.05$ significant , $\mathrm{P} \leq 0.01$ highly significant , $\mathrm{P} \leq 0.001$ very highly signif 


\section{Discussion:}

class. It is approved as an appetite Phentermine (phenyl-tertiary-butylamine) is an appetite suppressant of the amphetamine and phenethylamine suppressant to help reduce weight in obese patients when used short-term and combined with exercise, diet, and behavioral modification (Nelson and Gehlert 2006). It is typically prescribed for individuals who are at increased medical risk because of their weight and works by helping to release certain chemicals in the brain that control appetite. Many authors recorded harmful effects due to chemical drugs fenfluramine, dexfenfluramine, look-alike, 3,4-methelene dioxymeth-amphetamine , diethylepropion hydrochloride (Tenuate), Dnorpseudoephedrine (mirapro-N) and sibutramine which prescribed as appetite suppressant and obesity treatment (Conductier et al., 2005; Nordheim et al. 2006) . In contrast, Games et al., (2000) recorded no side effect for chemical drugs as fenproporex, sibutramine and orlisat (xinical). The present study revealed significant decrease of rat's body weight after 30 days of treatment with apple-lite, mirapro- $\mathrm{N}$ and tenuate, while non significant changes of body weight in the treated groups were recorded after the recovery period. Appetite suppressants loss efficacy when given chronically. The mechanisms are unknown . The present work showed that all three treatments resulted in a significant decrease in skin-fold thickness of gluteal, back and belly regions of rats after treatment period. This effect still exists after recovry period except the skin-fold thickness of belly region of apple-lite treated group which showed insignificant change. These findings agreed with and concomitant to the results of body weight. Studies in healthy overweight patients with or without type 2 diabetes have shown that Orlistat helps with weight loss properties and improves lipid levels and glucose serum levels as well as insulin concentration (Sjostrom et al. 1998). It may therefore be particularly helpful in the treatment of metabolic side-effects of atypical antipsychotics as modification of eating habits and increase in physical activity are more difficult to investigate and would thus represent additional burden for immediate family members.

The hypophagic effects of sibutramine and its metabolite are attributed in part to their $\alpha$ 1-adrenergic effects (Jackson et al. 1997). Hindbrain adrenergic neurons orchestrate multiple concurrent glucoregulatory responses involved in feeding and appetite control (Ritter et al. 2006). Apart from the central effects, $\alpha 2 \mathrm{~A}$ adrenoceptors are involved in the inhibition of subcutaneous fat lipolysis, which favors weight gain(Langin 2006). Sibutramine, a noradrenergic and serotonergic reuptake inhibitor approved for the longterm treatment of obesity, induces satiety, prevents decline in metabolic rate associated with hypocaloric diets (Hainer et al. 2006) and causes weight loss especially when combined with behavioral therapy (Berkowitz et al. 2003; Hansen et al. 2001). However, there are large differences in weight loss among individuals treated with sibutramine. Sibutramine reduced the maximum calorie ingestion in a challenge meal in humans (Vazquez Roque et al. 2007) and fundic accommodation in dogs (Xu et al. 2002) suggesting that its effects on weight loss may be mediated centrally (e.g., at the appetite center) or peripherally by changing satiation. The degree of weight loss at 4 weeks predicted weight loss at 12 weeks, consistent with analysis of pooled data from 7 studies of sibutramine-induced weight loss showing that $2 \mathrm{~kg}$ weight loss at 1 month has high sensitivity but low specificity as an indicator of long-term success among nondiabetic subjects ( Finer et al. 2006). The drug reduces food intake by increasing satiety and attenuates the fall in metabolic rate which occurs during weight loss, probably by stimulating thermogenesis. 
Several clinical studies assessing the effectiveness and safety of sibutramine in weight reduction and maintenance suggested that sibutramine is overall a safe and welltolerated agent (James et al. 2000).

The present study showed insignificant increase of liver enzymes, significant increase in LDH and non-significant changes in the lipid profile after 30 days of treatment of rats with apple-lite, mirapro-N and tenuate, while non significant changes of in liver enzymes in the three treated groups were recorded after the recovery period. These may be due the drug attenuates the fall in metabolic rate ( Finer et al. 2006).

\section{Conclusion:}

The changes in liver function enzymes (AST and ALT, acid phosphatase) associated with the treatment with apple-lie, mirapro- $\mathrm{N}$ and tenuate suggested some restriction upon the use of them even with the decrease in the lipid profile, so it did not raise major safety issues.

\section{References:}

1- Alemany M., Remesar, X. Lopez, J.A. and Fernandez, I. (2003): Drug strategies for the treatment of obesity. Drugs 6:566-572.

2- Andersen T, Boldrin M Golay A, Vazquez Roque MI, Camilleri M and Clark M.M., et al. (2007): Alteration of gastric functions and candidate genes associated with weight reduction in response to sibutramine. Clin Gastroenterol Hepatol. 5:829-837.

3- Aronne LJ (1998): Long-term treatment with the lipase-inhibiting agent orlistat (Xenical) is well tolerated by obese patient. J. Am. Diet, Assoc.,98: A13.

4- Berkowitz RI, Wadden TA and Tershakovec A.M., et al. (2003): Behavior therapy and sibutramine for the treatment of adolescent obesity: a randomized controlled trial. JAMA. 289:1805-1812.

5- Berkowitz RI, Wadden TA, Tershakovec AM, Cronquist JL. (2003): Behavior therapy and sibutramine for the treatment of adolescent obesity: a randomized controlled trial. JAMA., 289(14):1805-12.
6- Conductier G, Crosson C, Hen R, Bockaert J, Compan V. (2005): 3,4-Nmethlenedioxymetham-phetamine-induced hypophagia is maintained in 5-HT1B receptor knockout mice, but suppressed by the 5-HT2C receptor antagonist RS102221.

Neuropsychoph-armacology. 30:1056-1063.

7- Doumas BT (1975): Standards for total serum protein assays. A collaborative study. Clin. Chem., 21: 1159-1161.

8- Finer N, Ryan DH, Renz CL, Hewkin AC. (2006): Prediction of response to sibutramine therapy in obese non-diabetic and diabetic patients. Diabetes Obes Metab.2(2):206-213.

9- Finer N., Ryan DH and Renz CL et al., (2006): Prediction of response to sibutramine therapy in obese non-diabetic and diabetic patients. Diabetes Obes-Metab;8:206-213.

10- Fossati P and Medici R (1987): Abstract book: international symposium on cholesterol control and Radiovascular diseases: Prevention and Therapy.

11- Franzini L $R$ and Grimes WB (1976): Skinfold measures as. the criterion of change in weight control studies. Behavior Therapy, 7: 256-2

12- Glazer G (2001): Long-term Pharma-cotherapy of Obesity. Archives of internal medicine.161:15.

13- Gokcel A, Gumurdulu $Y$ and Karakose $H$ (2002): Evaluation of the safety and efficacy of sibutramine, orlistat and metformin in the treatment of obesity. Diabetes Obes Metab 4:4955.

14- Hainer V, Kabrnova K, Aldhoon B, Kunesova $M$ and Wagenknecht $M$ (2006): Serotonin and norepinephrine reuptake inhibition and eating behavior. Ann N Y Acad Sci. 1083:252-69.

15- Hanefeld $M$ and Sachse $G$ (2002): The effects of orlistat on body weight and glycemic control in overweight patients with type 2 diabetes: a randomized, placebo-controlled trial. Diabetes Obes Metab;4(6): 415-23.

16- Hansen D, Astrup A, Toubro S, Finer N, Kopelman P, Hilsted J, Rössner S, Saris W, Van Gaal L, James W, (2001): Predictors of weight loss and maintenance during 2 years of treatment by sibutramine in obesity. Results from the European multi-centre STORM trial. Sibutramine Trial of Obesity Reduction and Maintenance. Int J Obes Relat Metab Disord. (4):496-501.

17- Hansen DL, Astrup A and Toubro S (2001): Predictors of weight loss and maintenance during 2 years of treatment by sibutramine in 
obesity. Results from the uropean multi-centre STORM trial. Int J Obes. 25:496-501.

18- Hilger E, Quiner S, Ginzel I, Walter H , Saria L, Barnas C (2002): The Effect of Orlistat on Plasma Levels of Psychotropic Drugs in Patients With Long-term Psychopharmacotherapy. Journal of Clini Psychopharmacolo, 22(1): 68-70.

19- Hilger E, Quiner S, Ginzel I,Walter H, Saria $L$ and Barnas $C$ (1998): The effect of orlistat on plasma levels of psychotropic drugs in patients with longterm HP, et al. Randomised placebocontrolled trial of orlistat for weight loss and prevention of weight regain in obese patients. Lancet;352:167-72.

20- Jackson HC, Needham AM, Hutchins LJ, Mazurkiewicz SE, Heal DJ (1997): Comparison of the effects of sibutramine and other monoamine reuptake inhibitors on food intake in the rat. Br J Pharmacol.121(8):1758-62. James W P , Astrup, A Finer N,

21- Hilsted,J Kopelman P, Rössner S, Saris W H, Van Gaal L F (2000): Effect of sibutramine on weight maintenance after weight loss: a randomised trial. STORM Study Group. Sibutramine Trial of Obesity Reduction and Maintenance. The Lancet, 356(9248): 2119-2125

22- Kind PR and King EJ (1954): Estimation of plasma phosphatase by determination of hydrolysed phenol with antipyrin, Journal of Clinical Pathology 7, 322-32. Knight JA, Anderson S and Rawle JM (1972): Chemical basis of the sulfophosphovanillin reaction for estimation total serum lipids. Clin. Chem., 18:199-202.

23- Langin D (2006): Adipose tissue lipolysis as a metabolic pathway to define pharmacological strategies against obesity and the metabolic syndrome. Pharmacological Research. 53,6, 482491.

24- Milan I Siest G and Schielf MJ (1981): Interpretation des examines de laboratoire, Karger Ed., pp: 206-223. Nelson DL and Gehlert DR (2006): Central nervous system biogenic amine targets for control of appetite and energy expenditure."(HTML). Endocrine ;29 (1):49-60.
25- Nordheim, UN, Janet RD, Karol D, Patrick H and Karl G (2006): Cardiovascular responses to melanocortin 4-receptor stimulation in conscious unrestrained normotensive rats. Peptides 27,2,438-443.

26- Raabo E (1963): Determination of serum lactic dehydrogenase by the tetrazolium salt method. Scard. J. Clin. Lab. Invest., 15: 233.

27- Reitman S and Frankel S (1975): A colourimetric method for the determination of serum glutamic puruvic transaminases. Am. J. Clin. Pathol., 28: 56.

28- Ritter S, Dinh TT and Li AJ (2006): Hindbrain catecholamine neurons control multiple glucoregulatory responses. Physiol Behav.89(4):490-500.

29- Rojkin ML, Olguin DE and Marian MC (1974): Protein astotales del sureo causes mas frecuentes de error en la roaccion del Biurret Nuevo reactive calino esTable. Biog. Del Atlantico, V. pp: 1163-1193.

30- Scheen AJ, Ernest $P$ and Letiexhe MR (1999):Pharmacy-clinics medication of the month: Orlistat (xenical). Rev Med Liege. 54(3):192-196. Siest G and Schielf MJ (1981): Interpretation des examines de laboratoire, Karger Ed., pp: 206-223.

31- Sjostrom L Rissanen A Andersen T Boldrin M (1998): A Randomised placebo-controlled trial of orlistat for weight loss and prevention of weight regain in obese patients. Lancet. 352, 167-173.

32- Vazquez Roque MI, Camilleri M, Clark MM, Tepoel DA, Jensen MD, Graszer KM, Kalsy SA, Burton DD, Baxter KL, Zinsmeister AR (2007): Alteration of gastric functions and candidate genes associated with weight reduction in response to sibutramine. Clin Gastroenterol Hepatol.(7):829-837.

33- Webster D (1977): Albumin standards and measurement of serum albumin with bromochresol green. Clin. Chem., 23: 663-666.

34- Xu Y, Ohinata K, Meguid MM, Marx W, Tada T, Chen C, Quinn R and Inui A. (2002): Gastric bypass model in the obese rat to study metabolic mechanisms of weight loss. 


\section{تأثير بعض عقاقير التخسيس المخفضة للوزن على بعض}

\section{المعايير الكيموحيوية و الفسيولوجية فى الفئران}

ايمان جمال الدين عزت هلال* ، على شحات **، فهمى جاد السيد***

جامعة الاز هر كلية علوم (بنات) قسم علم الحيوان* ، جامعة الملك سعود كلية علوم(بنات)

قسم علوم الحياة **، جامعة المنصورة كلية العلوم (بنات) قسم علم الحيوان

\section{المقدمة:}

تهتم الدراسة بتأثير بعض العقاقير المنقصة للوزن و تأثير تناولها على الصحة العامة و منها أبل-ليت

$$
\text { (طبيعية) و مير ابرو - إن (كيميائية) و التتويات (ألياف كيميائية). }
$$

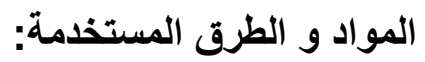

استخدمت الدراسة أربعوناً من ذكور الفئران البيضاء و التي تزن حوالي 130 جم و قسمت كالتالي:

1- المجموعة الضابطة: (10 فئران ) لم تتم معالجتها بأي عقار

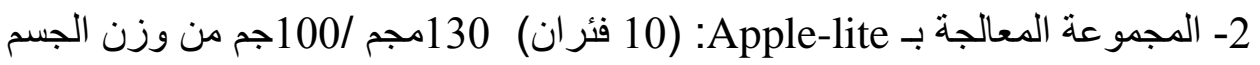
3- المجمو عة المعالجة بـ Mirapro-N (10 فئران) 14:14مجم/ 100جم من وزن الجسم

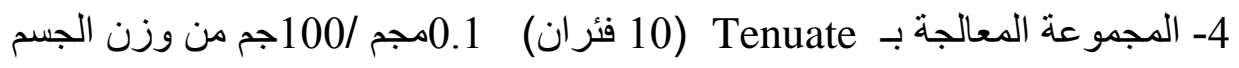

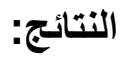

أظهرت المجمو عات المعالجة وخاصة بالعقاقير الكيميائية تغييرات معنوية ذات دلالات إحصائية في مستويات

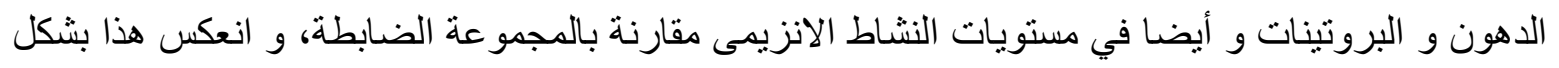
ملحوظ على سمك إنثناءات الجلا ووزن الجسم.

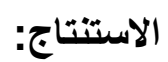

توصي الدراسة باستخدام المواد الطبيعية و تنظيم الوجبات الغذائية المتزنة لعدم اللجوء للعقاقير المخلقة كيميائية لما لها من تأثيرات سلبية على الصحة العامة. 